\title{
Cattle distribution, habitats, and diets in the Sierra Nevada of California
}

\author{
JOHN G. KIE AND BRIAN B. BOROSKI
}

\begin{abstract}
Authors are research wildlife biologist, U.S. Forest Service, Pacific Northwest Research Station, 1401 Gekeler Lane, La Grande, Ore. 97850, and research wildlife biologist, U.S. Forest Service, Pacific Southwest Research Station, 2081 East Sierra Avenue, Fresno, Calif. 93710. At the time of the research Kie was also with the Pacific Southwest Research Station.
\end{abstract}

\begin{abstract}
Cattle have been used to control shrubs following timber harvesting in the Sierra Nevada of California, although their effectiveness varies between sites. Although cattle home ranges, habitat use, and diets are known for many forested ecosystems, the coniferous forests of the Sierra Nevada are different because shrubs are the most common understory species, with fewer herbaceous species than elsewhere in the western United States. As a first step in evaluating factors that influence cattle distribution and their potential effectiveness in controlling competing vegetation in the Sierra Nevada, we used radio-telemetry collars on cows to determine their home ranges and habitat use patterns. Mean home range size was 162.80 ha in 1986 and 278.83 ha in 1987. When choosing home ranges, cattle showed the greatest affinity for riparian habitat, followed by clearcuts, secondgrowth forest, and burned areas. Distances from streams to cattle locations were significantly $(P<0.01)$ less $(\bar{X}=59.3 \mathrm{~m}$ in 1986, and $\bar{X}=60.1 \mathrm{~m}$ in 1987) than were distances from streams to random points ( $\overline{\mathrm{X}}=130.4 \mathrm{~m})$. Based on microhistological analysis of fecal fragments, cattle diets included seeded grasses and shrubs mostly from upland sites, but forbs primarily from riparian sites. We suggest the need for water and the relative lack of herbaceous forage in the understory of mixed-conifer forests in the Sierra Nevada resulted in the strong, summer-long preference for riparian habitats. The effectiveness of grazing in controlling competing vegetation following timber harvest may be related to the proximity of the clearcuts to riparian habitats but this specific hypothesis remains to be tested.
\end{abstract}

Key Words: cattle home ranges, cattle habitats, cattle diets, Sierra Nevada, California

Mixed-conifer forests on the west slope of the Sierra Nevada in California provide both timber and summer forage for cattle. Cattle, in turn, are useful in reducing the vigor and abundance of competing herbaceous and shrub species following timber harvest without detrimental impact to tree seedlings, although their effectiveness varies between sites (Kosco and Bartolome 1983, Allen and Bartolome 1989). Distribution patterns of cattle are known to be influenced by forage type, quality, quantity, water availability,

We thank Wayne Owen, Calvin Pratt, Marya Robbins and our other field assistants, Deborrah Young for microhistological food habit analysis, James Bartolome for reviewing a draft of this paper, and Jim Baldwin for advice on statistical methods.

Manuscript accepted 20 Jan. 1996. and physiography in other ecosystems (Mueggler 1965, Cook 1966, Bryant 1982, Hart et al. 1991, Pinchak et al. 1991, Smith et al. 1992). However, the coniferous forests of the Sierra Nevada are different because shrubs are the most common understory species (Storer and Usinger 1963), with few herbaceous species as in other western forests (Ffolliott 1983, Mitchell 1983). Herbaceous plants in the Sierra Nevada are found in greatest abundance in meadow-riparian areas (Larson and Wolters 1983, Kie and Myler 1987, Allen 1989).

We hypothesized that factors influencing cattle distribution in the Sierra Nevada may have an impact on their effectiveness in controlling competing vegetation following timber harvest. As a first step in testing this hypothesis, we examined cattle home ranges, habitat preferences, and diets on Blodgett Forest. We then refined the original hypothesis about how these factors might limit the use of cattle to control herbaceous and shrub canopy cover in harvested timber compartments, which still remains to be tested.

\section{Materials and Methods}

This study was conducted during the summers of 1986 and 1987 at the University of California's Blodgett Forest Research Station, $24 \mathrm{~km}$ northeast of Placerville in central California (Fig. 1). Blodgett Forest comprises about 1,200 ha within the mixedconifer zone between 1,200 and $1,450 \mathrm{~m}$ in elevation on the west slope of the Sierra Nevada. Trees species present on Blodgett Forest included incense cedar (Calocedrus decurrens [Torrey] Florin), white fir (Abies concolor [Gordon and Glend.] Lindley), sugar pine (Pinus lambertiana Douglas), Douglas-fir (Pseudotsuga menziesii [Mirbel] Franco), California black oak (Quercus kelloggii Newb.), ponderosa pine (Pinus ponderosa Laws.), and tan oak (Lithocarpus densiflora Hook. and Arn.). Shrubs included deerbrush (Ceanothus integerrimus Hook. and Arn.), mountain whitethorn (C. cordulatus Kellogg), manzanita (Arctostaphylos spp.), and sierra gooseberry (Ribes roezlii Regel). White alder (Alnus rhombifolia Nutt.) and willows (Salix spp.) were found near streams (Airola and Barrett 1981). Intermediate wheatgrass (Elytrigia intermedium [Host] Nevski) and orchard grass (Dactylis glomerata L.) had been seeded on upland sites such as near roads for erosion control. Wooly mullein (Verbascum thapsus L.) and sweetclover (Meliotus alba Medikus) were found on disturbed areas. Meadow vegetation 
included rushes (Juncus spp.), sedges (Carex spp.), willow herb (Epilobium spp.), false solomon's seal (Smilacina spp.), groundsel (Senecio triangularis Hook.), and other forbs.

During our study, only the southern portion of Blodgett Forest ( $657 \mathrm{ha}$, Fig 1.) was grazed by cattle. All of this area was potentially available to cattle because water was plentiful and most slopes were less than $20 \%$ (Airola and Barrett 1981). We defined four habitat types for this area: second-growth forest (regenerating forest with trees $>6 \mathrm{~m}$ tall), burned (recently subjected to understory prescribed fire), clearcuts (with trees $\leq 6 \mathrm{~m}$ tall), and riparian (any area within $50 \mathrm{~m}$ of a stream; Fig. 1). Secondgrowth forest was the most common habitat (327 ha, 12 habitat blocks, block size $(\bar{X}=27.26$ ha). Riparian habitat was the second most common, and consisted of long, linear polygons (199

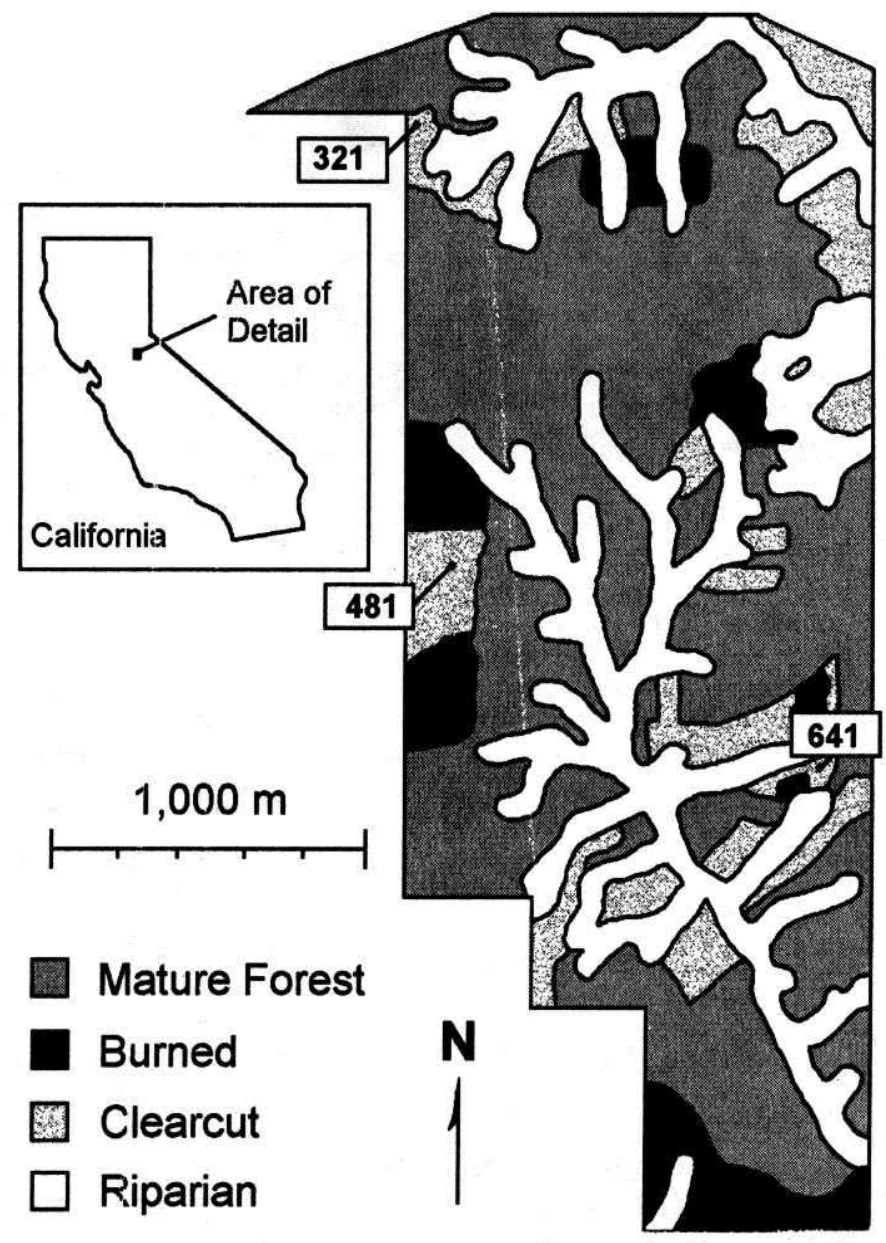

Fig. 1. Habitat map of the southern portion of Blodgett Forest Research Station. See text for detailed description of habitat types. Clearcuts numbered 481, 641, and 321 are referred to in the text.

ha, 4 blocks, block size $\overline{\mathrm{X}}=49.71$ ha). Clearcuts covered 83 ha (18 blocks, block size $\bar{X}=4.61$ ha) and burned habitats covered 48 ha (9 blocks, block size $\bar{X}=5.28$ ha; Fig. 1 ).

Cattle stocking rates were about 40 animal units each summer from late May through September, for a stocking rate of about 16 ha/animal unit (Kosco and Bartolome 1978). In 1986, 6 cows were fitted with radio-telemetry collars (Telonics Inc., Mesa,
Ariz., commercial names provided for information only, no endorsement by the U.S. government is implied) and followed during the months of July and August. In 1987, another 6 cows were collared, and followed from mid-June until mid-September. Monitoring was conducted during 8-hour shifts rotated over all 24 hours of the day. We attempted to locate each cow twice per day, and obtained a total 681 estimated locations. Of these, 267 were verified by visual sightings. The remaining 414 locations were estimated by triangulating on the source of the radio signal from 2 known locations using a directional, hand-held Yagi antenna.

To test the precision of the locations determined by triangulation, we placed radio-telemetry collars at 46 known locations, and found that the mean angular error by field personnel was \pm 13.83 degrees (median $=12.00$ degrees, $\mathrm{SD}=10.34$ degrees). We used this angular error to estimate the sizes of the error polygons (Springer 1979) for the 414 estimated locations. We partially compensated for the large angular error by getting closer to each cow when taking readings (distance $\bar{X}=250 \mathrm{~m}$, median $=217 \mathrm{~m}$, $\mathrm{SD}=141 \mathrm{~m}$ ), which resulted in a mean error polygon of $2.42 \mathrm{ha}$ (median $=1.17$ ha, $\mathrm{SD}=3.98$ ha; Loft et al. 1989). We eliminated from further analysis any estimated location with an error polygon greater than 5 ha ( $n=48$ locations), reducing our total sample size to 633 locations. Finally, we had difficulty in regularly locating 1 cow in 1986, obtaining only 4 locations. We dropped that animal from the analysis because of the inability to estimate her home range, resulting in a total sample size of 629 locations for 11 cows over both years (267 visual locations and 362 locations estimated by triangulation).

Cow home ranges were determined using the $95 \%$ contour adaptive kernel technique (Worton 1989) as implemented in program CALHOME (Larkin and Halkin 1994, Kie et al. 1996). Each home range was first calculated using an estimated optimum smoothing parameter (Worton 1989). Because the cow locations occurred in clumped, non-random distributions, we also calculated the home ranges with a smoothing parameter $80 \%$ of the estimated optimum. For 9 of the 11 cows, this resulted in a similarly-shaped home range but a better fit to the data as indicated by a lower least-squares cross-validation score (Worton 1989). Because of sampling and estimation variability, portions of some cow home ranges occurred outside the Blodgett Forest fence (Fig. 2). We report the sizes of both the raw home range estimates, as well as those constrained by fences.

To estimate habitat preferences by cows, we calculated the proportions of the 4 different habitat types within each cow's home range for 1986 and 1987, as well as within the study area as whole (second-order selection, Johnson 1980). Because of the lack of independence between cows, which traveled in small groups, we averaged those proportions for all cows in 1986 and all those in 1987 . We then used the yearly averages to calculate log-ratio habitat preference ranks (Aebischer et al. 1993). This procedure estimated pairwise preferences among all habitat types, and the number of positive comparisons were used to rank each type. Insufficient sample size ( $n=2$ years) made it impossible to statistically test for differences between the ranks.

We also examined the distances cows were found away from streams and compared those to the distances from a random set of points to streams. Again, because estimated cow locations may not have been independent either within or between cows, we used only 1 location chosen at random (provided that it was an 
Table 1. Log-ratio habitat preference values, and number of positive values in each row used for ranking preferences. Habitats are ranked in order of preference by the number of positive values (Aebischer et al. 1993). For example, riparian habitat is preferred over all 3 other habitats, receiving 3 positive values in both years.

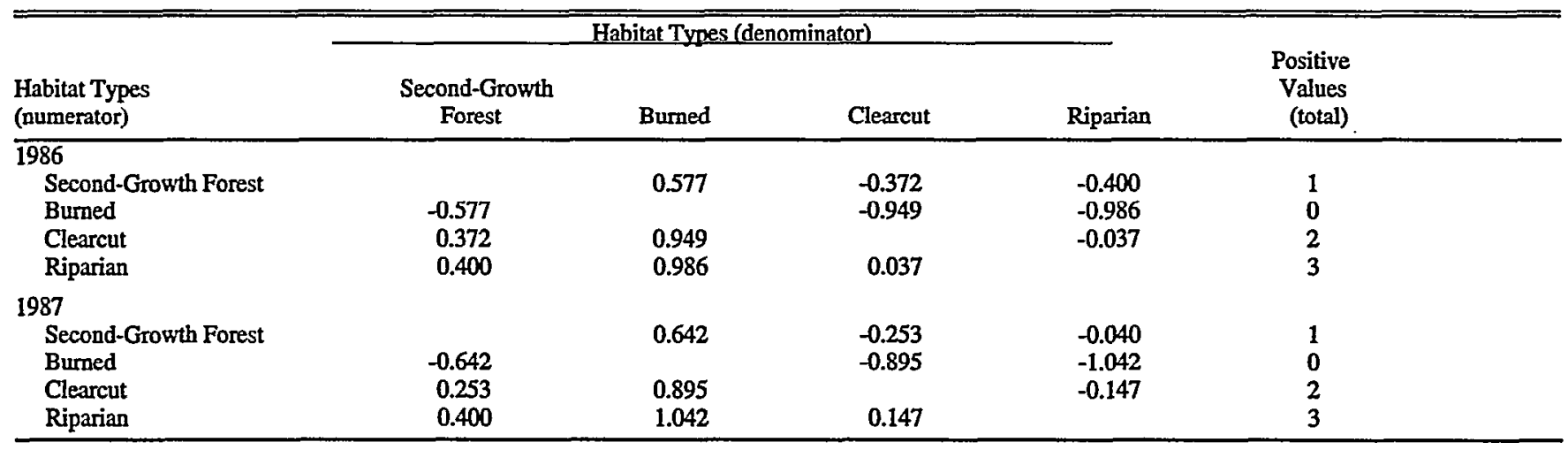

estimated location within the fenced boundary of Blodgett Forest) for a randomly-chosen cow each day we sampled (16 days in 1986,48 days in 1987, 64 days total). Distances from streams to cow locations were compared for 1986 and 1987 , and between the pooled data for both years and the distances from streams to 64 randomly-chosen points, using 2-sample T-tests with squareroot transformations.

To determine cattle diets, we collected fresh fecal samples every 2 wccks from mid-June until late September in both 1986 and 1987. Each bi-weekly sample represented a composite of material gathered from 3 cow droppings. Fecal samples were airdried and then stored frozen before being sent to the Fecal Analysis Lab at the University of Arizona where they were analyzed using a microhistological technique (Sparks and Malechek 1968). Frequency of occurrence of plant species fragments were determined for 20 microscope fields-of-view on 10 slides (200 fields-of-view total) for each sample (Holechek and Vavra 1981, Holechek et al. 1982). Those frequencies were then converted to a density estimate and reported on a relative density basis, which closely approximates dietary percentages on a dry weight basis (Sparks and Malechek 1968).

\section{Results}

The estimated mean size of cow home ranges in 1986 was $173.20 \mathrm{ha}(\mathrm{SD}=68.95 \mathrm{ha}, \mathrm{n}=5)$. However, because sampling and estimation errors, some cow locations and portions of some home ranges were placed outside the study area boundary fence (Fig. 1). By excluding those portions of the home ranges outside the fence, the mean size of the home ranges in 1986 was 162.80 ha (SD = 57.81). The mean home range size in 1987 was 321.33 ha $(S D=54.03, n=6)$, and those portions constrained by fences averaged 278.83 ( $\mathrm{SD}=64.05$ ha; Fig. 1). The 1987 home ranges were larger than those obtained in 1986 because they represent more locations collected over a 4-month sampling period (June-September, 479 locations) rather than over a 2-month period (July-August, 150 locations). As the cows shifted their areas of use over the summer, their cumulative summer-long home ranges became progressively larger.

Although second-growth forest, riparian, clearcut, and burned habitats made up $50,30,13$, and $8 \%$ of the study area respectively, those habitats averaged $42,39,16$, and $5 \%$ of cow home ranges in 1986 and 43, 39, 14, and 3\% in 1987. Calculating log- ratio habitat preference values (Aebischer et al. 1993) for all cows in 1986 and all cows in 1987 resulted in the same habitat preference rankings for both years: riparian areas were the most preferred, followed by clearcut, second-growth forest, and burned habitats (Table 1). When choosing home ranges, cattle may have avoided the extreme southern portion of the study area because of steep slopes, although we did not quantify this factor.

Cows were found closer to streams than were random points (Table 2). There was no difference between stream-to-cow distances collected during the 2 years $(P>0.10)$, but when data for both years were pooled, stream-to-cow distances were less than stream-to-random-point distances $(P<0.01)$. None of the cow

Table 2. Distances from streams to 1986 cow locations, 1987 cow locations, and random points at Blodgett Forest. Mean distances from streams to cow locations were not different between 1986 and 1987 (2-sample $t$ test with square root transformation, $P>0.10$ ), but pooled were less than mean distances from streams to random points $(P<0.01)$.

\begin{tabular}{lccc}
\hline \hline & $\mathrm{n}$ & $\overline{\mathrm{X}}$ & $\mathrm{SD}$ \\
\hline & & $(\mathrm{m})$ & $(\mathrm{m})$ \\
1986 cow locations & 16 & 59.3 & 54.7 \\
1987 cow locations & 48 & 60.1 & 48.1 \\
Random points & 64 & 130.4 & 105.2 \\
\hline
\end{tabular}

locations were farther from water than $194 \mathrm{~m}$ in 1986 or $221 \mathrm{~m}$ in 1987 , although some of the random points were up to $424 \mathrm{~m}$ away.

Cattle diets were similar between the 2 years (Table 3 ). Despite previous research indicating that cattle on Blodgett Forest can be used to control deerbrush in clearcut areas (Kosco and Bartolome 1983, Allen and Bartolome 1989), we found evidence of deerbrush in cattle diets only in August during both years (and only 12.0\% in August 1986 and 5.6\% in August 1987).

There was a striking relationship between the appearance of riparian versus non-riparian plant species in the diet when examined by forage class (Table 3, Fig. 3). When cows ate grass-like plants, they most often took non-native species used for erosion control on upland sites such as intermediate wheatgrass and orchard grass rather than grasses common on the riparian sites. Similarly, most of the browse they consumed were upland species as well. Most of the forbs eaten however, consisted of willow herb and false Solomon's seal, both riparian species (Table 3, Fig. 3). We caution however, that sedges were common 

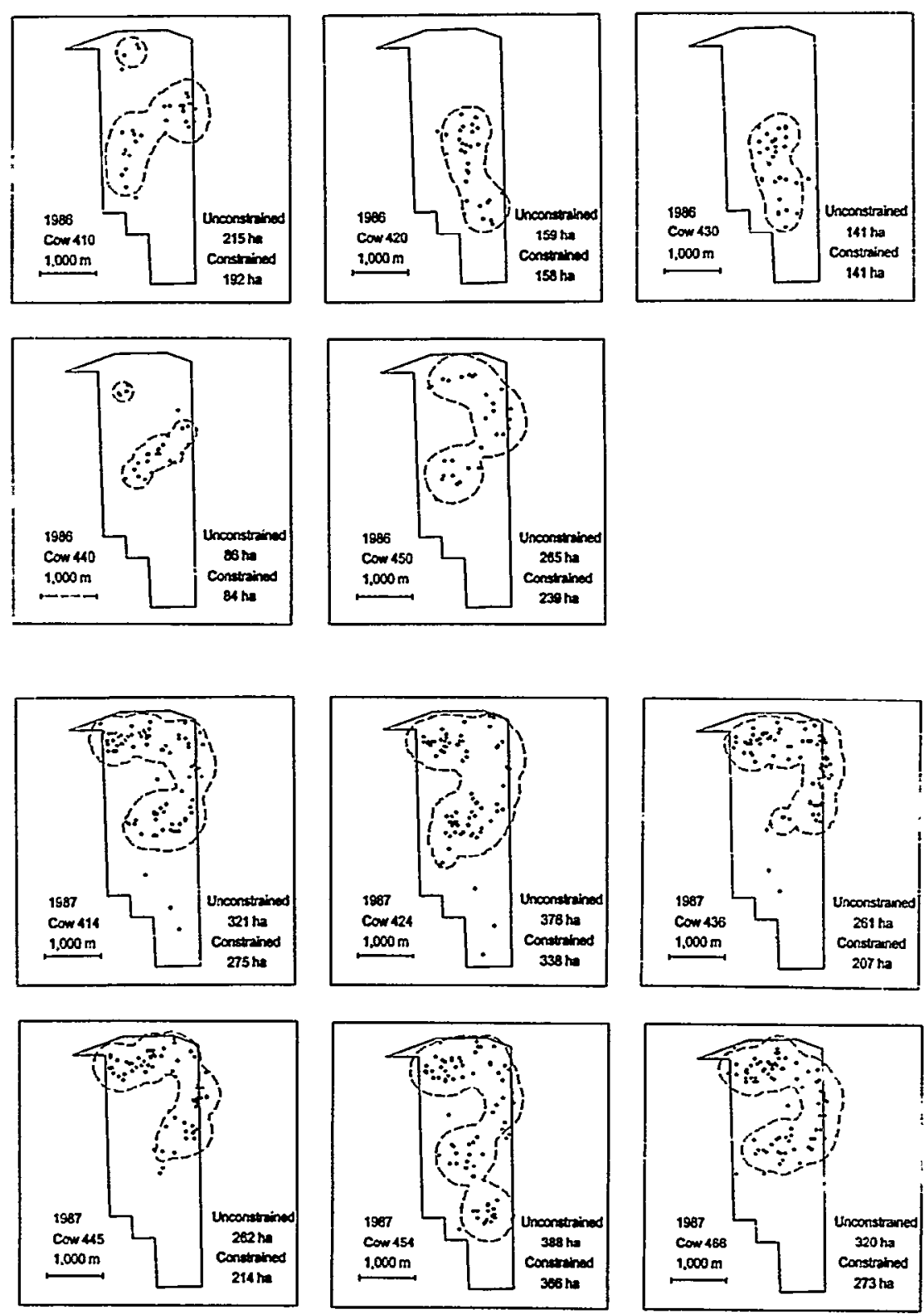

Fig. 2. Adaptive kernel 95\% contour home ranges for 5 cows in 1986 and 6 cows in 1987 on Blodgett Forest. Home range sizes are shown for total, unconstrained estimates, and for those portions of the home ranges constrained by fences. Cow locations and home range portions outside the fenced boundary represent sampling and estimation errors.

in the riparian areas, but may not have been detected in the feces in proportion to dietary intake (J. Bartolome, D. Young, pers. comm.).

\section{Discussion and Conclusions}

Factors that affect cattle distribution on western rangelands include slope steepness, distance to water, forage abundance, amount of dense shrub cover, distance to salt, and other factors (Mueggler 1965, Cook 1966). In most cases, cattle concentrate in riparian habitats because of the proximity to water, gentle terrain, and abundant, nutritious forage (Bryant 1982, Roath and Krueger 1982, Schulz and Leininger 1990, Smith et al. 1992). For example in north-central Oregon, small riparian meadows made up 3-
$5 \%$ of the study area but $24-47 \%$ of all cattle observations were made in those meadows (Gillen et al. 1984). In Wyoming, 77\% of observed cattle use occurred with $366 \mathrm{~m}$ of water, and although $65 \%$ of the land area was beyond $723 \mathrm{~m}$ from water, only $12 \%$ of the observed cattle use occurred there (Pinchak et al. 1991). By comparison, cattle on Blodgett Forest were found at an average distance of about $60 \mathrm{~m}$ from water (Table 2), and $75 \%$ of the observations were within $103 \mathrm{~m}$ in 1986 and within $97 \mathrm{~m}$ in 1987.

Changes in use of riparian habitats over the course of a summer grazing period have been reported, although regional differences seem to occur. Cows concentrated near streams early in summer and under lighter stocking rates in Wyoming, and farther away from streams later in the summer and with heavier stocking rates (Hart et al. 1991). Conversely, in Montana, cattle made most use 
of riparian habitats in late summer and early fall (Marlow and Pogacnik 1986). In our study, cattle chose home ranges with a preponderance of riparian habitats throughout the summer grazing period, as has been reported for elsewhere in the Sierra Nevada of California (Loft et al. 1991). They also shifted their use within their season-long home ranges as the summer progressed.

Cattle can be used as tool to control deerbrush in areas that have been clearcut in the Sierra Nevada. In previous studies on Blodgett Forest, mule deer (Odocoileus hemionus Rafinesque) and cattle reduced shrub cover on clearcuts (Kosco and Bartolome 1978, Kosco and Bartolome 1983, Allen and Bartolome 1989). In these studies, shrub control was greater on clearcuts adjacent to riparian habitats (numbers 641 and 321; Fig. 1) than on 1 close to but not adjacent to a streamside zone (number 481; Fig. 1). We concluded that cows on Blodgett Forest favor riparian habitats and are on average found about $60 \mathrm{~m}$ away from streams, less than half the distance that would be expected than if they were distributed at random (Table 2). It may be that the differences in shrub control reported between clearcuts may have been in part the result of proximity to water.

Despite the levels of deerbrush control reported earlier (Kosco and Bartolome 1983, Allen and Bartolome 1989) we found deerbrush in cattle diets only in August and only in small to moderate amounts. Little use of riparian grasses and woody species such as willows seemed to occur on Blodgett Forest, unlike elsewhere in the Sierra Nevada (Loft et al. 1987). Most grasses consumed were non-native species commonly used for erosion control (Table 3). While a large proportion of cattle diets consisted of grasses and browse other than deerbrush from upland sites, cattle ate forbs extensively when foraging in riparian habitats (Fig. 3).

Why cattle show such a strong preference for riparian and meadow habitats in the Sierra Nevada may be partially a result geological history. The Sierra Nevada is a relatively young, faultblock mountain range and much of its current topography has been shaped by an active period of glaciation and repeated local faulting over the last million years (Storer and Usinger 1963). The resulting channels created by snowmelt have served to transport and redistribute eroded parent material along stream courses and in basins and other low-lying areas. Soils in other areas are often poorly developed, and support plants that are adapted to periodic drought. Herbaceous plants in the Sierra Nevada are found in greatest abundance in meadow-riparian areas (Larson and Wolters 1983, Kie and Myler 1987, Allen 1989) where soils are deeper and can hold moisture throughout the summer growing season. Shrubs are the most common understory species in Sierra Nevada mixed-conifer forests, with few herbaceous species as in other western forests (Ffolliott 1983, Mitchell 1983). This relative lack of herbaceous forage on upland sites likely contributes to cattle preferences for riparian habitats and for their proximity to water.

Cattle distribution in relation to streams and riparian habitat on Blodgett Forest may have implications for the extent to which grazing can be used as a tool to manage vegetation in clearcut

Table 3. Percentage of items in cattle diets on BFRS based on microhistolgical examination of fecal fragments.

\begin{tabular}{|c|c|c|c|c|c|c|c|c|c|}
\hline \multirow[b]{2}{*}{ Species } & \multirow[b]{2}{*}{ Riparian? } & \multicolumn{4}{|c|}{1986} & \multicolumn{4}{|c|}{1987} \\
\hline & & Jun & Jul. & Aug. & Sep. & Jun. & Jul. & Aug. & Sep. \\
\hline & & $-\cdots$ & -- & $\cdots-$ & $\cdots$ & $\cdots$ & $-\cdots$ & $\cdots$ & -- \\
\hline \multicolumn{10}{|l|}{ Grass-like Plants } \\
\hline Seeded grasses ${ }^{1}$ & No & 33.3 & 8.6 & 16.2 & 78.7 & 14.2 & 0.0 & 32.2 & 18.2 \\
\hline \multicolumn{10}{|l|}{$\begin{array}{l}\text { Forbs } \\
\text { Willow herb }\end{array}$} \\
\hline False solomon's seal & & & & & & & & & \\
\hline $\begin{array}{l}\text { (Smilacina spp.) } \\
\text { Groundsel }\end{array}$ & Yes & 7.2 & 23.7 & 3.8 & 9.0 & 24.5 & 0.0 & 21.6 & 5.4 \\
\hline $\begin{array}{l}\text { (Senecio triangularis Hook.) } \\
\text { Wooly mullein }\end{array}$ & Yes & 0.0 & 14.5 & 0.0 & 0.0 & 3.6 & 0.0 & 4.6 & 3.1 \\
\hline $\begin{array}{l}\text { (Verbascum thapsus L.) } \\
\text { Sweetclover }\end{array}$ & No & 2.2 & 0.0 & 0.5 & 0.0 & 3.0 & 0.3 & 3.5 & 0.0 \\
\hline \multicolumn{10}{|l|}{ Browse } \\
\hline $\begin{array}{l}\text { (Alnus rhombifolia Nutt.) } \\
\text { Black oak }\end{array}$ & Yes & 2.3 & 2.8 & 2.5 & 1.0 & 0.0 & 0.0 & 3.0 & 0.0 \\
\hline $\begin{array}{l}\text { (Quercus kelloggii Newb.) } \\
\text { Tan oak }\end{array}$ & No & 17.8 & 0.0 & 10.2 & 0.0 & 0.0 & 0.0 & 0.0 & 0.0 \\
\hline $\begin{array}{l}\text { (Lithocarpus densiflorus Hook. and Am.) } \\
\text { Sierra gooseberry }\end{array}$ & No & 8.0 & 14.1 & 8.4 & 0.0 & 32.8 & 39.4 & 6.5 & 0.0 \\
\hline $\begin{array}{l}\text { (Ribes roezlii Regel.) } \\
\text { Deerbrush }\end{array}$ & No & 5.1 & 24.0 & 7.9 & 11.3 & 11.4 & 6.1 & 0.0 & 50.8 \\
\hline $\begin{array}{l}\text { (Ceanothus integerrimus Hook. and Arn.) } \\
\text { Mountain whitethorn }\end{array}$ & No & 0.0 & 0.0 & 12.0 & 0.0 & 0.0 & 0.0 & 5.6 & 0.0 \\
\hline (C. cordulatus Kellogg) & No & 0.0 & 0.0 & 0.5 & 0.0 & 0.0 & 8.4 & 1.1 & 0.0 \\
\hline Other browse & & 0.9 & 0.0 & 0.5 & 0.0 & 0.0 & 0.0 & 0.0 & 19.2 \\
\hline
\end{tabular}

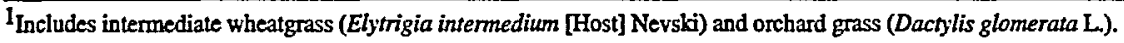



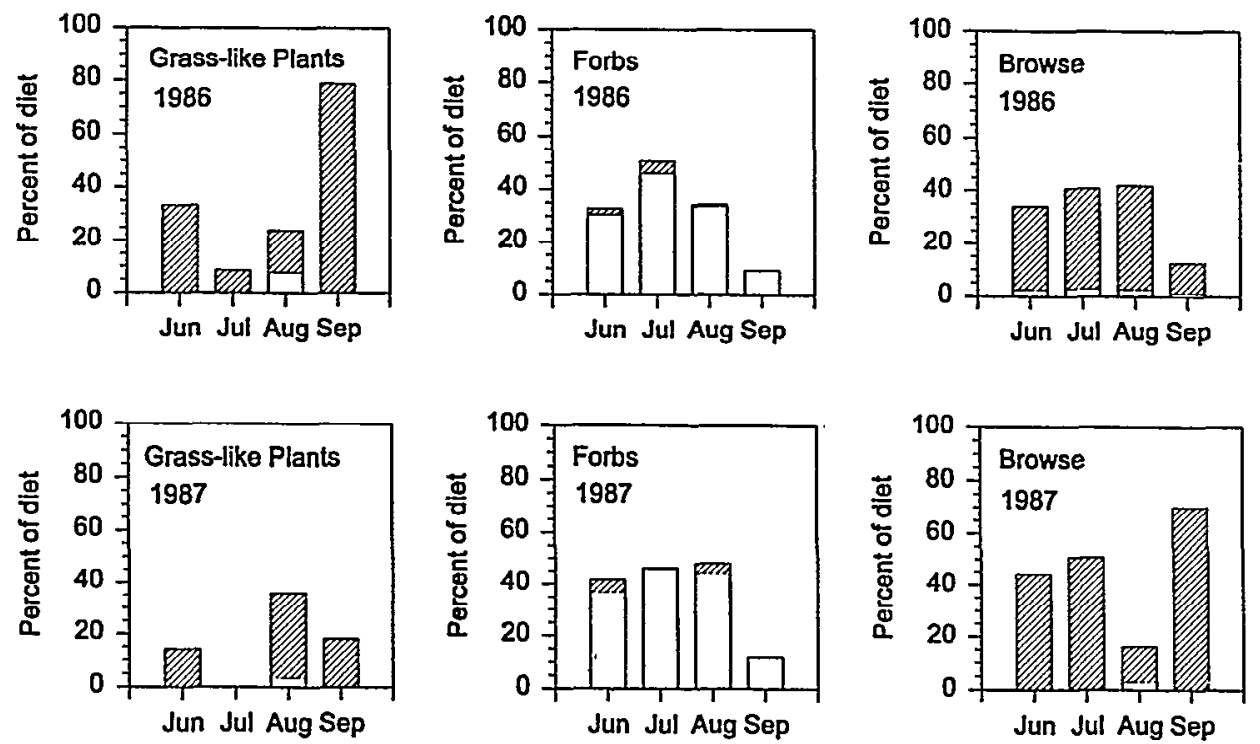

Riparian Species

Non-riparian Species

Fig. 3. Percentage of items in cattle diets in 1986 and 1987 on Blodgett Forest based on microhistological examination of fecal fragments.

areas. Current forest practice rules applicable to private lands in California place restrictions on the proximity of clearcuts to water courses. Depending on the water class and slope of the terrain along the water course, harvest may be prohibited within 15-61 $\mathrm{m}(50-200 \mathrm{ft})$ from the water course (California Department of Forestry and Fire Protection 1991).

A means of redistributing cattle use into clearcuts away from riparian areas would provide for better control of competing vegetation in harvest compartments throughout the forest. The use of salt blocks on upland sites has not been effective in reducing cattle use of riparian habitats (Wagnon 1968, Bryant 1982). Placement of supplemental feed on upland sites has been used to draw cows away from riparian habitats on foothill ranges in California (McDougald et al. 1989), although the success of that technique is unknown on montane summer ranges, nor are the potential adverse effects of concentrating cows on upland sites. Without the aid of fencing or herders, the use of free-ranging cattle to assist resource managers in forest regeneration may be limited to areas near riparian habitats.

\section{Literature Cited}

Aebischer, N.J., P.A. Robertson, and R.E. Kenward. 1993. Compositional analysis of habitat use from animal radio-tracking data. Ecol. 74:1313-1325.

Airola, D.A. and R.H. Barrett. 1981. Vertebrates of Blodgett Forest Research Station, El Dorado County, California - An annotated species list. Univ. of Califomia, Division of Agr. Sci. Spec. Pub. 3267.

Allen, B.H. 1989. Ten years of change in Sierran Stringer meadows: an evaluation of range condition models, p. 102-108. In: Abell, D.L. (tech. coord.), Proceedings of the California Riparian Systems Conference. USFS, Gen. Tech. Rep. PSW-110, Berkeley, Calif.

Allen, B.H. and J.W. Bartolome. 1989. Cattle grazing effects on understory cover and tree growth in mixed conifer clearcuts. Northwest Sci. 63:214-220.
Bryant, L.D. 1982. Response of livestock to grazing zone exclusion. J. Range Manage. 35:780-785.

California Dept. of Forestry and Fire Protection. 1991. Article 6. Water course and lake protection, p. 26-30. In: California Forest Practice Rules, Sacramento, Calif.

Cook, C.W. 1966. Factors affecting utilization of mountain slopes by cattle. J. Range Manage. 19:200-204.

Ffolliott, P.F. 1983. Overstory-understory relationships: southwestern ponderosa pine forests, p. 13-18. In: E.T. Bartlett and D.R. Betters (eds.), Overstory-understory relationships in western forests. Western Regional Pub. 1. Colorado State Univ. Exp. Sta., Fort Collins, Colo.

Gillen, R.L., W.C. Krueger, and R.F. Miller. 1984. Cattle distribution on mountain rangeland in northeastern Oregon. J. Range Manage. 37:549-553.

Hart, R.H., K.W. Hepworth, M.A. Smith, and J.W. Waggoner, Jr. 1991. Cattle grazing behavior on a foothill elk winter range in southeastern Wyoming. J. Range Manage. 44:262-266.

Holechek, J.L. and M. Vavra. 1981. The effect of slide and frequency observation numbers on the precision of microhistological analysis. J. Range Manage. 34:337-338.

Holechek, J.L., M. Vavra, and R.D. Pieper. 1982. Botanical composition determination: a review. J. Range. Manage. 35:309-315.

Johnson, D.H. 1980. The comparison of usage and availability measurements for evaluating resource preference. Ecol. 61:65-71.

Kie, J.G. and S.A. Myler. 1987. Use of fertilization and grazing exclusion in mitigating lost meadow production in the Sierra Nevada, California, USA. Environ. Manage. 11:641-648.

Kie, J.G., J.A. Baldwin, and C.J. Evans. 1996. CALHOME: a program for estimating animal home ranges. Wildl. Soc. Bull. 24:342-344..

Kosco, B.H. and J.W. Bartolome. 1978. Grazing mixed conifer forests. Calif. Agr. 32(5):5-7.

Kosco, B.H. and J.W. Bartolome. 1983. Effects of cattle and deer on regenerating mixed conifer clearcuts. J. Range Manage. 36:265-268.

Larkin, R.P. and D. Halkin. 1994. A review of software packages for estimating animal home ranges. Wildl. Soc. Bull 22:274-287.

Larson, F.R. and G.L. Wolters. 1983. Overstory-understory relationships: mixed conifer forests, p.21-25. In: E.T. Bartlett and D.R. Betters (eds.), Overstory-understory relationships in western forests. Western Regional Pub. 1. Colorado State Univ. Exp. Sta., Fort Collins, Colo. 
Loft, E.R., J.W. Menke, and J.G. Kie. 1991. Habitat shifts by mule deer: the influence of cattle grazing. J. Wildl. Manage. 55:16-26.

Loft, E.R., C.J. Evans, K.E. Ragotskie, and J.G. Kie. 1989. Design and accuracy considerations for wildlife telemetry studies: some examples from ungulates. Trans. Western Section Wildl. Soc. 25:91-97.

Loft, E.R., J.W. Menke, J.G. Kie, and R.C. Bertram. 1987. Influence of cattle stocking rate on the structural profile of deer hiding cover. J. Wild. Manage. 51:655-664.

Marlow, C.B. and T.M. Pogacnik. 1986. Cattle feeding and resting patterns in a foothills riparian zone. J. Range Manage. 39:212-217.

McDougald, N.K., W.E. Frost, and D.E. Jones. 1989. Use of supplemental feeding locations to manage cattle use on riparian areas of hardwood rangelands, p. 124-126. In: Abell, Dana L. (tech. coord.), Proceedings of the California Riparian Systems Conference. USFS, Gen. Tech. Rep. PSW-110, Berkeley, Cal.

Mitchell, J.E. 1983. Overstory-understory relationships: douglas fir forests, p. 27-34. In: E.T. Bartlett and D.R. Betters (eds.), Overstoryunderstory relationships in western forests. Western Regional Pub. 1. Colorado State Univ. Exp. Sta., Fort Collins, Colo.

Mueggler, W.F. 1965. Cattle distribution on steep slopes. J. Range Manage. 18:255-257.
Pinchak, W.E., M.A. Smith, R.H. Hart, and J.W. Waggoner, Jr. 1991. Beef cattle distribution patterns on foothill range. J. Range Manage. 44:267-275.

Roath, L.R. and W.C. Krueger. 1982. Cattle grazing and behavior on forested range. J. Range Manage. 35:332-338.

Schulz, T.T. and W.C. Leininger. 1990. Differences in riparian vegetation structure between grazed areas and exclosures. J. Range Manage. 43:295-299.

Smith, M.A., J.D. Rodgers, J.L. Dodd, and Q.D. Skinner. 1992. Habitat selection by cattle along an ephemeral channel. J. Range Manage. 45:385-390.

Storer, T.I. and R.L. Usinger. 1963. Sierra Nevada natural history. Univ. of Calif. Press, Berkeley, Calif.

Sparks, D.R. and J.C. Malechek. 1968. Estimating percentage dry weight in diets using a microscope technique. J. Range Manage. 21:264-265.

Springer, J.T. 1979. Some sources of bias and sampling error in radio triangulation. J. Wildl. Manage. 43:926-935.

Wagnon, K.A. 1968. Use of different classes of range land by cattle. Univ. of Calif. Exp. Sta. Bull. 838.

Worton, B.J. 1989. Kernel methods for estimating the utilization distribution in home-range studies. Ecol. 70:164-168.

\section{Research Leader \\ USDA Agricultural Research Service Temple, Texas}

POSITION/LOCATION: The USDA Agricuttural Research Service invites qualified candidates to apply for the position of Research Leader at the Grassland Soll and Water Research Laboratory at Temple. Texas. The position is for a Rangeland Specialist, Ecologist, or Plant Physiologist and Research Leader of the Grassland Protection Unit.

RESPONSIBILITIES: The successful candidate will lead a multidisciplinary team charged with the improvement of productivity of rangelands through: 1) development of an understanding of the fundamental ecosystem processes that control productivity of vegetation: 2) a resolution of the uncertainty about the effects of rising atmospheric. $\mathrm{CO}_{2}$ on ecosystem processes, net primary productivity, species composition, and the sustainable use of rangelands; and 3) effective biological control programs for woody and herbaceous woeds on grazing lands. The incumbent's personal and team research will deal with the effects of increasing atmospheric $\mathrm{CO}_{2}$ on the ecosystem processes. As Research Leader, the incumbent will provide technical and administrative leadership to the unit including identification of problem areas, establishing priorities and goals, and management of human, fiscal, and physical resources allocated to the unit.

QUALIFICATION/SALARY: Applicants must possess a Bachelor's or higher degree in range management, biology. plant physiology or a related scientific discipline. For specific qualifications, see vacancy announcement. The appointment is a permanent full-time position and requires U.S. citizenship. Salary commensurate with experience $(\$ 61,348$ to $\$ 72,162)$.

TO APPLY: For an application package contact Sandra Markum at 817-770-6540. For additional information on the position contact: Dr. Clarence Richardson at 817-770-6500.

EFFECTIVE DATE: Appications must be marked ARS-D65088 (5-6-017) and postmarked by December $13,1996$. USDAARS IS AN EQUAL OPPORTUNITY EMPLOYER 